\title{
Role of ICT in Higher Educational Administration in Uganda
}

\author{
Kayiwa Shafik Juma ${ }^{1}$, Dr. Md. Abu Raihan ${ }^{1 *} \&$ Dr. Che Kum Clement ${ }^{1}$ \\ ${ }^{1}$ Department of Technical and Vocational Education (TVE), Islamic University of Technology (IUT), \\ Bangladesh \\ *Dr. Md. Abu Raihan, E-mail: maraihan.iut@gmail.com
}

\begin{abstract}
The study was on the role of Information and Communication Technology (ICT) in higher educational administration in Uganda. The study population comprised of four universities. Convenience sampling was used to obtain the sample size of 48 admininistrators from the population. The study aimed at identifying the roles of ICT in higher educational administration and a survey method was employed to investigate the study. Related literatures were reviewed from journals and past researches, data was collected using a well designed and validated questionnaire, the data was statistically analyzed and interpreted using weighted average and chi square test. The findings of this study revealed that ICT greatly enhanced educational administrator's performance through improving cross communication at the managerial level, quick access to needed information, provides media and enhances information accuracy, analyzing data fast and effectively, their knowledge and skills a networked platform for collaborative work, motivates administrators through access to new information, for research purposes and enhances research skills of administrators, evaluation of staff and students is made easier, helps administrators in result processing, analyzes data quickly and accurately, reduces on workload, good and secure storage of information, improves coordination of tasks and activities. Therefore, the findings reveal that the proprietors of universities should procure more ICT facilities and equipment in order to ensure maximum efficiency and effectiveness in all dimensions of educational administration.
\end{abstract}

\section{Keywords}

ICT, higher educational administration, Uganda

\section{Introduction}

Information and Communication Technologies (ICT) application in education has gained popularity over the past 20 years and this has led to changes in the way educational institutions carry out activities and processes not only in teaching and learning process or monitoring of students' progress but it has also had an impact in educational administrative processes and management of higher educational institutions. Adebayo (2013) defines Information and Communication Technology (ICT) as technology that supports activities involving the creation, storage, manipulation and communication of information, the application and use of ICT has led to the emergence of different forms of microelectronic and telecommunications tools such as laptops and computers, computer networks, the Internet digital 
printers and mobile technology, which enable administrators to record, store, process, retrieve, and transmit information (Kokt \& Koelane, 2013).

While various researches (Guma et al., 2013; Williams et al., 2001; Watson, 2001) have investigated the roles ICT plays in making teaching and learning process effective in higher institutions of learning as well as the problems faced in successful integration, quite few researches have been carried out to investigate the roles of ICT and its application in higher educational administration. One of the principle factors for smooth running and achievement of institutional goals is effective and realistic administration. Administration is a process of planning activities and utilizing human and imperial resources with an aim of accomplishing of goals and objectives of a particular organization or institution. It calls for the ability of the administrators to make the right decisions at the right time to fulfill the predetermined goals. In educational institutional setting therefore, administration has been extended as a service activity or tool through which the fundamental objectives of the institutional process may be optimized more efficiently when allocating human and material resources as well as making the best use of existing resources (Opara \& Onyije, 2014).

Thus within higher educational administration, ICT is implemented for the development of electronic applications for the management of administrative transactions and records, as well as for the rendering of well-organized and prompt information services (i.e., electronic register, electronic curriculum, digital lesson material, electronic monitoring of school progress).

There are several uses of ICT in administration of higher institutions of learning: ICT can increase school efficiency and reduce unnecessary bureaucracy in school administration, with ICT, the administrators can discharge their duties by using computers and Internet in solving school problems at hand and in carrying out their day-to-day assignment especially as it relates to having a reliable information system, ICT can play a major role in reducing the work load of the administrators and staff especially in analyzing information like analyzing student academic performance hence much time is saved. ICT also helps in managing student admission, student records and examination records, the monitoring and evaluation of staff, planning for school activities, curriculum development, financial management and information dissemination, promotes communication between school units, parents, and principal administration (Oboegbulem \& Ugwu, 2013). Therefore, these factors will increase the efficiency of the higher institutions of learning administration, if ICT facilities are properly implemented and utilized. However, no studies have been conducted to investigate this research area in Uganda, therefore the aim of this study was to identify the roles of ICT in higher educational administration in Uganda. 


\section{Literature Review}

\subsection{The Concept of Information and Communication Technology in Educational Administration}

ICT (Opara \& Onyije, 2014) are facilities, tools or resources that could be used to process, store, preserve, access, retrieve, and disseminate information with ease. It could be seen as the engine for growth and tool for empowerment, with profound implications for education, change, and socio-economic development, the dream of any institution is an effective and efficient managerial process to accomplish their needs and goals. The knowledge of computer application software such as spreadsheet, computer aided design, and databases are important skills in institutional administration. The complexity of institutional system requires more demand from the institutional administrators in processing of relevant data in an attempt to provide information for the governing bodies, institution and other institutional agencies for decision making towards quality assurance and transformational development. Therefore educational administrators need to have basic information on students and teachers, institutional supplies, and how much the system is spending on various inputs, in order to make the most basic resource allocation decisions (Iwu \& Olke, 2009).

\subsection{The Role of ICT in Educational Administration}

ICT plays a vital role in supporting powerful, efficient management and administration in education sector. It is specified that technology can be used right from student administration to various resource administration in an education institution (Maki, 2008). Clarke-okah et al. (2009) identified multiple uses of ICT application for the university administration as follows:

First, ICT technology can process voluminous records quickly, meticulously and impeccably; Second, technology can generate reliable and consistent records; Third, records and data produced are searchable and quickly retrievable; Fourth, digital records save space, a premium cost to institutions; Fifth, technology saves human resources for data entry and servicing student admission and registration. With advanced scanning technology, completed application forms can be read into the databases in a matter of seconds. Other software like Learning Management Systems (LMS) e.g., the open source Moodle allow students to register for courses directly online, pay online and get course information online; Sixth, technology can expand the geographical boundary for student intake and facilitate cross-border higher education. Using ICT in higher education administration is fundamentally about harnessing technology for better planning, setting standards, effecting change and monitoring results of the core functions of universities (Krishnaveni \& Meenakumari, 2010). Therefore, ICT plays a major role in enhancing of administrative efficiency and effectiveness in the following ways.

\subsection{Organization of Information}

Institution administrators need to have basic information on students and teacher flows. For example, categorize data on student/staff by sex, class, state of origin, performance in schools etc. They organize data into an easily accessible format and can be easily stored and retrieved from the computer. 


\subsection{Analyzing the Data Quickly and Accurately}

Adesida (2001) not only does ICT facilitate information exchange, they are deepening the process of creating new modes of sharing ideas, and reducing the costs of collecting and analyzing information. Use of ICT will help in analyzing the available data quickly and accurately with the help of organized data. The institutional management systems arrange the data in the form of graphs, polygons, tables, means, and standard deviation etc. for analysis purpose. These are the readymade data obtained within the short period of data entry for analysis of the data accurately and quickly.

\subsection{Increasing Coordination}

Because of lack of timely, structured and efficient information sharing, there is a chance of duplication of data collection and compilation. This leads to lack of coordination between departments and directorates, institutional management systems databases help to avoid the redundancy or duplication of data thereby enhancing data coordination with departments.

\subsection{Effective and Quick Decision Making}

The information present in the educational institutions is in fragmented and fuzzy form, it is generally compiled in non-standard formats. Manual handling of huge data is very difficult and causes delayed information collection and compilation. This will affect in decision-making process for quality education, but with the use of ICT, well-organized and analyzed data is readily available to foster effective and quick decision-making.

\subsection{Proper Utilization and Allocation of Resources}

It is very difficult to the track the teachers as well as students movement and progress at college/university, state and central level. It very difficult to track the assets and ultimately this is causing the impact on financial planning and budgeting and efficient tracking of available resources and its utilization, with the use of ICT it is easier to track and allocate institutional resources thereby aiding in the planning and budgeting.

\subsection{Access to the Stakeholders}

Institutional information systems manage information about students and staff so that it can be easily accessible to the parents, students, directors and the institutional administrators.

\subsection{Student Performance Improvement}

Institutional information systems hold the information on students' achievement so that the management can monitor the performance of the institutions and intervene where progress is weak. It can also help of sharing of good practices where progress is good.

\subsection{Efficient Management of Education and Institution}

ICT improves management of education through more efficient administrative process, including human resource management, monitory, evaluation and resources sharing. With the ready available data for analysis the administrators can make quick decisions about the improvement in education and as well as improvement in the functioning of institution. 


\subsection{Enhancement of Effective Communication and Knowledge Sharing}

The integration of ICT for example internet, emails, chat and instant messaging programmes, discussion boards and news groups in institutional administration has opened new ventures for communicating. It is convenient; cheap and allows for administrators to share and exchange ideas instantly (Chinien, 2003). Due to the recent development in ICT, we now live in a world without borders since the world has become a global village, this allows institutional administrators use ICT for improved communication as a process of transforming thoughts, sharing and imparting of information among different schools, and knowledge experts locally and all over the world which in return enhances the administration of their schools (Iwu \& Olke, 2009).

\subsection{Enhancement of Planning}

Institutional information systems hold the information on student, staff, resources etc. This could be used by institutional administrators to plan and make decisions on the basis of accurate and readily available facts. They budget the school expenditure and plans for replacement of both obsolete and repairs of broken down equipment or institutional facilities.

\subsection{Improvement of Monitoring}

Institutional administrators use computers in monitoring various areas in the institution, such as teacher's performance, monitoring student's progress and achievements.

\subsection{Managed Instruction}

Institutional administrators to use computer in scheduling courses, classrooms, inventory and personnel control, recording and reporting attendance, school accounting, storage and students results management. This is capable of generating results, retrieving lecture timetable, enlisting of courses and registration online.

\section{Methodology}

The study was descriptive in nature and the survey method was used, the population of the study comprised of educational administrators from the four selected universities in Uganda Convenience sampling was used to select twelve administrators from each of the selected universities, the sample size was $48(12 * 4)$. The researcher used questionnaires for gathering information regarding the opinions of administrators about the role of ICT in higher educational in Uganda, The questionnaire had both structured and unstructured questions relevant to the study. A total of 40 (83.3\%) fully completed questionnaires were returned. Chi square test and Weighted Average (WA) were used to analyze and interpret the data.

\section{Analysis and Interpretation of Data}

The role of ICT in higher educational administration have been presented in the following table. 
Table 1. Analysis of the Roles Played by ICT in Higher Educational Administration

\begin{tabular}{|c|c|c|c|c|c|c|c|c|c|c|}
\hline $\mathbf{S} / \mathbf{N}$ & Statement & $5(\mathrm{SA})$ & $4(\mathrm{~A})$ & $3(U)$ & 2(D) & $1(\mathrm{SD})$ & WA & & Sig. & df \\
\hline 1 & $\begin{array}{l}\text { ICT delays and complicates } \\
\text { effective and quick decision } \\
\text { making }\end{array}$ & $\begin{array}{l}4 \\
(10.0)\end{array}$ & $\begin{array}{l}8 \\
(20.0)\end{array}$ & $\begin{array}{l}2 \\
(5.0)\end{array}$ & $\begin{array}{l}10 \\
(25.0)\end{array}$ & $\begin{array}{l}16 \\
(40.0)\end{array}$ & 2.35 & 15.0 & .005 & 4 \\
\hline 2 & $\begin{array}{l}\text { ICT aids in analyzing the data } \\
\text { quickly and accurately }\end{array}$ & $\begin{array}{l}26 \\
(65.0)\end{array}$ & $\begin{array}{l}12 \\
(30.0)\end{array}$ & $\begin{array}{l}1 \\
(2.5)\end{array}$ & $\begin{array}{l}0 \\
(0.0)\end{array}$ & $\begin{array}{l}1 \\
(2.5)\end{array}$ & 4.55 & 42.2 & .000 & 3 \\
\hline 3 & $\begin{array}{l}\text { ICT is relevant for facilitating } \\
\text { information gathering \& } \\
\text { dissemination }\end{array}$ & $\begin{array}{l}18 \\
(45.0)\end{array}$ & $\begin{array}{l}20 \\
(50.0)\end{array}$ & $\begin{array}{l}1 \\
(2.5)\end{array}$ & $\begin{array}{l}1 \\
(2.5)\end{array}$ & $\begin{array}{l}0 \\
(0.0)\end{array}$ & 4.38 & 32.6 & .000 & 3 \\
\hline 4 & $\begin{array}{l}\text { ICT helps prevent financial } \\
\text { dishonesty }\end{array}$ & $\begin{array}{l}10 \\
(25.0)\end{array}$ & $\begin{array}{l}15 \\
(37.5)\end{array}$ & $\begin{array}{l}11 \\
(27.5)\end{array}$ & $\begin{array}{l}4 \\
(10.0)\end{array}$ & $\begin{array}{l}0 \\
(0.0)\end{array}$ & 3.78 & 6.2 & .102 & 3 \\
\hline 5 & $\begin{array}{l}\text { ICT enhances monitoring of } \\
\text { educational facilities\& resources }\end{array}$ & $\begin{array}{l}20 \\
(50.0)\end{array}$ & $\begin{array}{l}15 \\
(37.5)\end{array}$ & $\begin{array}{l}4 \\
(10.0)\end{array}$ & $\begin{array}{l}1 \\
(2.5)\end{array}$ & $\begin{array}{l}0 \\
(0.0)\end{array}$ & 4.35 & 24.2 & .000 & 3 \\
\hline 6 & $\begin{array}{l}\text { ICT facilitates adequate data } \\
\text { storage }\end{array}$ & $\begin{array}{l}21 \\
(52.5)\end{array}$ & $\begin{array}{l}13 \\
(32.5)\end{array}$ & $\begin{array}{l}4 \\
(10.0)\end{array}$ & $\begin{array}{l}2 \\
(5.0)\end{array}$ & $\begin{array}{l}0 \\
(0.0)\end{array}$ & 4.33 & 23.0 & .000 & 3 \\
\hline 7 & $\begin{array}{l}\text { ICT improves coordination of tasks } \\
\text { and activities }\end{array}$ & $\begin{array}{l}18 \\
(45.0)\end{array}$ & $\begin{array}{l}21 \\
(52.5)\end{array}$ & $\begin{array}{l}0 \\
(0.0)\end{array}$ & $\begin{array}{l}1 \\
(2.5)\end{array}$ & $\begin{array}{l}0 \\
(0.0)\end{array}$ & 4.40 & 17.5 & .000 & 2 \\
\hline 8 & Using ICT reduces my workload & $\begin{array}{l}22 \\
(55.0)\end{array}$ & $\begin{array}{l}15 \\
(37.5)\end{array}$ & $\begin{array}{l}0 \\
(0.0)\end{array}$ & $\begin{array}{l}3 \\
(7.5)\end{array}$ & $\begin{array}{l}0 \\
(0.0)\end{array}$ & 4.40 & 13.9 & .001 & 2 \\
\hline 9 & $\begin{array}{l}\text { Using ICT makes me less } \\
\text { productive }\end{array}$ & $\begin{array}{l}2 \\
(5.0)\end{array}$ & $\begin{array}{l}5 \\
(12.5)\end{array}$ & $\begin{array}{l}0 \\
(0.0)\end{array}$ & $\begin{array}{l}14 \\
(35.0)\end{array}$ & $\begin{array}{l}19 \\
(47.5)\end{array}$ & 1.93 & 18.6 & .000 & 3 \\
\hline 10 & $\begin{array}{l}\text { ICT is not used effectively by my } \\
\text { institution to manage proper } \\
\text { utilization and allocation of } \\
\text { resources }\end{array}$ & $\begin{array}{l}5 \\
(12.5)\end{array}$ & $\begin{array}{l}7 \\
(17.5)\end{array}$ & $\begin{array}{l}3 \\
(7.5)\end{array}$ & $\begin{array}{l}14 \\
(35.0)\end{array}$ & $\begin{array}{l}11 \\
(27.5)\end{array}$ & 2.53 & 10.0 & .040 & 4 \\
\hline 11 & $\begin{array}{l}\text { Using ICT in my institution } \\
\text { enhances effective communication } \\
\text { and knowledge sharing }\end{array}$ & $\begin{array}{l}18 \\
(45.0)\end{array}$ & $\begin{array}{l}17 \\
(42.5)\end{array}$ & $\begin{array}{l}1 \\
(2.5)\end{array}$ & $\begin{array}{l}3 \\
(7.5)\end{array}$ & $\begin{array}{l}1 \\
(2.5)\end{array}$ & 4.20 & 38.0 & .000 & 4 \\
\hline 12 & $\begin{array}{l}\text { ICT slows educational planning } \\
\text { process }\end{array}$ & $\begin{array}{l}2 \\
(5.0)\end{array}$ & $\begin{array}{l}3 \\
(7.5)\end{array}$ & $\begin{array}{l}3 \\
(7.5)\end{array}$ & $\begin{array}{l}15 \\
(37.5)\end{array}$ & $\begin{array}{l}17 \\
(42.5)\end{array}$ & 1.95 & 27.0 & .000 & 4 \\
\hline 13 & $\begin{array}{l}\text { ICT does not improve skill } \\
\text { acquisition \& development }\end{array}$ & $\begin{array}{l}2 \\
(5.0)\end{array}$ & $\begin{array}{l}2 \\
(5.0)\end{array}$ & $\begin{array}{l}5 \\
(12.5)\end{array}$ & $\begin{array}{l}13 \\
(32.5)\end{array}$ & $\begin{array}{l}18 \\
(45.0)\end{array}$ & 1.93 & 25.8 & .000 & 4 \\
\hline 14 & ICT enhances data processing & $\begin{array}{l}21 \\
(52.5)\end{array}$ & $\begin{array}{l}17 \\
(42.5)\end{array}$ & $\begin{array}{l}2 \\
(5.0)\end{array}$ & $\begin{array}{l}0 \\
(0.0)\end{array}$ & $\begin{array}{l}0 \\
(0.0)\end{array}$ & 4.48 & 15.1 & .001 & 2 \\
\hline
\end{tabular}




\subsection{Results and Discussion}

According to the findings:

1) ICT facilitates effective and quick decision making because of the availability of different information management systems that avail quick and accurate information needed in making decisions;

2) The administrators strongly agree that ICT aids in analyzing the data quickly and accurately, this is possible through the usage of information management systems and analytical software that help administrators draw patterns from the available data for example analyzing a student's progressive academic performance as compared to the other students;

3) ICT is relevant in facilitating information gathering \& dissemination, Almost all the administrators agreed to using ICT in helping them gather information and distribute it to the concerned parties for example online gathering of student information and online dissemination of examination results;

4) It was found out that it was not statistically significant to say that ICT does help prevent financial dishonesty of which it is contrary to what the researcher had predicted;

5) It was found out that ICT helps in enhancing the monitoring of educational facilities \& resources through use of video cameras and management systems that track usage of the resources and facilities;

6) It was it was statistically significant to agree that ICT facilitates adequate data storage for example storing data on file servers and accessed through ftp (file transfer protocol) and also data about students, teachers, administrators stored in management systems;

7) It was statistically significant to agree that ICT improves coordination of tasks and activities;

8) It was statistically significant to agree that using ICT reduces administrator's workload; using ICT in administration automates various tasks and activities;

9) It was statistically significant to disagree that using ICT makes the administrator less productive, therefore ICT makes the administrators more productive;

10) It was found out ICT is not used effectively to manage proper utilization and allocation of resources;

11) It was statistically significant to agree that using ICT in administration enhances effective communication and knowledge sharing among the administrators;

12) It was statistically significant to disagree that ICT slows educational planning process, therefore ICT enhances the educational planning process;

13) It was statistically significant to disagree that ICT does not improve skill acquisition \& development, therefore ICT aids administrators in enhancing skill acquisition \& development;

14) It was statistically significant to agree that ICT enhances data processing, by help of computers and software that process data for administrators.

\subsection{Conclusion}

Considering the findings of the study, it was concluded that ICT has a significant role in higher educational administration in Uganda. It was found that ICT is relevant in facilitating effective and 
quick decision making, aiding analyzing data quickly and accurately, facilitating information gathering $\&$ dissemination, enhancing monitoring of educational facilities $\&$ resources, facilitating adequate data storage, improving coordination of tasks and activities, making administrators more productive, enhancing effective communication and knowledge sharing, facilitating fast educational planning process, improving skill acquisition \& development and enhancing data processing. Therefore, ICT should be fully integrated into the process of higher educational administration.

\section{Recommendations}

The following recommendations can be made for future actions so that there will be more use of ICT in higher educational administration in Uganda. The institutional executives and administrators should as a matter of urgency provide more ICT facilities, equipments and tools for providing solutions to administrational problems, The ownership of institutions should recognize the role and application of ICT to enhance qualitative and fast decision-making for successful educational administration, Administrators should build more confidence in using ICT tools. Training on ICT usage should be provided to all administrators for maximum productivity, the administrators should be provided with technical support to problems that may occur because of ICT usage.

\section{References}

Adebayo, S. S. (2013, September). The impact of application of Information and Communications Technology (ICT) in the administration of polytechnics in ogun state, Nigeria. International Journal of Students Research in Technology \& Management, 1, 505-515.

Adesida, O. (2001). African development bank economic research papers Governance in Africa: The Role for Information and Communication Technologies Governance in Africa. The Role for Information, 65, 9 .

Asankha, P., \& Yamano, T. (2011). Impacts of universal secondary education policy on secondary school enrollments in Uganda. Journal of Accounting, Finance and Economics, 1(1), 16-30. Retrieved from http://www.jafepapers.com/uploads/2011/july/2.pdf

Chinien, C. (2003). The Use of ICTs in Technical and Vocational Education and Training.

Clarke-okah, W., Ferreira, F., \& Kwan, A. (2009). ICTs for Higher Education: Background paper from the Commonwealth of Learning. In UNESCO World Conference on Higher Education.

Conole, G. (2012). ICT and general administration in educational institutions.

Guma, A., Haolader, F. A., \& Khushi, M. (2013). The Role of ICT to Make Teaching-Learning Effective in Higher Institutions of Learning in Uganda. International Journal of Innovative Research in Science, Engineering and Technology, 2(8), 4061-4073.

Iwu, A., \& Olke, G. A. (2009). Information and communication technology and Programmed Instruction for the attainment of educational goals in Nigeria's secondary schools. Journal of the Nigeria Association for Educational Media and Technology. 
Kokt, D., \& Koelane, T. (2013). Reflecting on Information and Communication Technology (ICT) in marketing from a marketer's and student perspective. African Journal of Business Management, 7(31), 3098-3108. http://dx.doi.org/10.5897/AJBM2013.7054

Krishnaveni, R., \& Meenakumari, J. (2010). Usage of ICT for Information Administration in Higher education Institutions-A study. International Journal of Environmental Science and Development, 1(3). Retrieved from http://www.ijesd.org/papers/55-D461.pdf

Kumar, N., Rose, R. C., \& D’Silva, J. L. (2008). Teachers' readiness to use technology in the classroom: An empirical study. European Journal of Scientific Research, 21(4), 603-616. http://dx.doi.org/10.1504/IJMIE.2008.016228

M.S.Saud, S., Babawuro, T., Lokman, Y., Buntat, Y., \& Noraffandy, A. G. (2011). Applicability of Information and Communication Technologies (ICTs) in the administration of Technical and Vocational Education and Training (TVET) in a knowledge-based society. International Journal of the Physical Sciences, 6(28), 6513-6520. http://dx.doi.org/10.5897/IJPS11.658

Maki, C. (2008). Information and Communication technology for administration and management for secondary schools in Cyprus. Journal of Online Learning and Teaching, 4(3), 18-20.

Meenakumari, J. (2011). Transforming Higher educational institution administration through ICT. IJACSA-International Journal of Advanced Computer Science and Applications, 2(8), 2009-2012. Retrieved from http://www.ijacsa.thesai.org

Ministry of Works Housing and Communications. (2003). National Information and Communication $\begin{array}{llll}\text { Technology Policy. } & \text { Retrieved }\end{array}$ http://researchictafrica.net/countries/uganda/2003_Uganda_National_ICT_Policy_Framework.doc

Nishimura, M., Yamano, T., \& Sasaoka, Y. (2008). Impacts of the universal primary education policy on educational attainment and private costs in rural Uganda. International Journal of Educational Development, 28, 161-175. http://dx.doi.org/10.1016/j.jjedudev.2006.09.017

Oboegbulem, A., \& Ugwu, R. N. (2013). The Place of ICT (Information and Communication Technology) in the Administration of Secondary Schools in South Eastern States of Nigeria, 3(4), 231-238. Retrieved from http://www.eric.ed.gov/?q=information+research\&ft=on\&ffl=dtyIn_2013\&ff2=subInformation $+\mathrm{T}$ echnology\&id=ED542971 \nhttp://files.eric.ed.gov/fulltext/ED542971.pdf

Opara, J., \& Onyije, L. (2014). Information and Communication Technologies (ICT): A panacea to achieving effective goals in institutional administration. International Letters of Social and Humanistic Sciences, 1, 81-87. http://dx.doi.org/10.5901/mjss.2013.v4n13p227

Rezaee, Z., Elam, R., \& Sharbatoghlie, A. (2001). Continuous auditing: The audit of the future. Managerial Auditing Journal. http://dx.doi.org/10.1108/02686900110385605

Saiti, A., \& Prokopiadou, G. (2009). Impact of information and communication technologies on school administration: Research on the Greek schools of secondary education. Lecture Notes in Computer Science (including Subseries Lecture Notes in Artificial Intelligence and Lecture Notes in 
Bioinformatics), 5693 LNCS, 305-316. http://dx.doi.org/10.1007/978-3-642-03516-6_26

Suhail, A., \& Sibichan, K. M. (2014). The Contribution of ICT in Higher Education: A multifaceted approach/n. IOSR Journal of Electronics and Communication Engineering (IOSR-JECE), 9(1), 60-63. Retrieved from http://www.iosrjournals.org/iosr-jece/papers/Vol9-Issue1/Version-5/K09156063.pdf

Syngellakis, K., \& Arudo, E. (2006, May). Education Sector Policy Overview Paper Uganda. Power UK. Uganda.

Unachukwu, G. O., \& Nwankwo, C. A. (2012). Rjopes Rjopes principals' readiness for the use ICT in school administration in anambra state of nigeria, 1(2), 114-120.

Watson, D. M. (2001). Pedagogy before Technology: Re-thinking the Relationship between ICT and Teaching. Education and Information Technologies, 6(4), 251-266. http://dx.doi.org/10.1023/a:1012976702296

Williams, D., Coles, L., Wilson, K., Richardson, A., \& Tuson, J. (2000). Teachers and ICT: Current use and future needs. British Journal of Educational Technology, 31(4), 307-320. http://dx.doi.org/10.1111/1467-8535.00164 